\title{
Envelhecimento e espaços de vida: olhares cruzados
}

A ideia de um dossier temático sobre envelhecimento na revista CIDADES, Comunidades e Territórios prendese com a importância de cruzar dois temas: envelhecimento e espaços de vida, com grande relevância social e estratégica nas politicas públicas ao nível do espaço urbano, mas também na oferta de serviços para os seniores. A questão ligada ao envelhecimento nas cidades está na agenda política internacional desde 2007, com o lançamento pela OMS do Guia Cidades Amigas da Pessoa Idosa. Em 2030 estima-se que 3 em cada 5 pessoas viverão em grandes centros urbanos e metade dessa população terá mais de 65 anos. Teremos assim uma nova sociedade mais envelhecida nos centros urbanos, que deve ser repensada em termos da sua organização, dos seus serviços e, por último, a própria cidadania que deve ser mais proactiva em relação às temáticas do envelhecimento.

Nesse contexto foi feito o convite à Rede REIACTIS (rede internacional sobre a idade, cidadania e integração sócio-económica) que integra investigadores das ciências sociais que pesquisam as questões do Envelhecimento e cidadania com vista a promover uma discussão em torno destas questões e obter assim várias respostas efectivas, coerentes e de fácil aplicação. Esta rede é constituída por investigadores de vários países tais como: França, Canadá, Espanha, Chile, Estados Unidos, Portugal, Bélgica, Suiça, entre outros, que pretendem a integração política, social e económica dos indivíduos e grupos sociais.

A REACTIS desenvolve projectos de investigação internacionais, bem como organiza a partilha de conhecimento, através de uma série de conferências ou simpósios. Em fevereiro de 2016 irá realizar em Lausanne (Suíça) de 10 a 12 de fevereiro, o $5^{\circ}$ Simpósio Internacional da Rede REIACTIS, intitulado "Envelhecimento e poderes para agir. Entre os recursos e as vulnerabilidades". Trata-se de uma coorganização da Haute École de Travail Social Suíça Ocidental (HES•SO) e do Centro Nacional de Investigação Suiço, este evento incidirá sobre o tema da dinâmica das vulnerabilidades e recursos relacionados com o avanço na idade.

Para além, da organização de conferências e simpósios, a rede REIACTIS também tem desenvolvido investigação internacional sobre seus eixos temáticos (envelhecimento e cidadania), com especial atenção à formação de novas gerações de investigadores. Este é o objetivo do projeto associativo Vida (REVA) que faz a partilha de conhecimento entre investigadores séniores e júniores sobre o tema da vida comunitária, participação social e voluntariado dos pensionistas. Este projecto conta ainda com a participação da Universidade de FrancheComté e Grenoble na França e as Universidades de Laval e Sherbrooke, Quebec.

A rede REIACTIS também promove um trabalho de divulgação da investigação científica através de uma estratégia editorial que dissemina o conhecimento na área de pesquisa das Ciências Sociais sobre o envelhecimento. É neste contexto que surge este dossier temático sobre envelhecimento, aproximando a temática do envelhecimento à dimensão territorial e das comunidades, dando uma nova visão através da análise destes temas que são analisados em separado e através da valorização da importância real do espaço na integração dos individuos, e em particular, dos séniores.

\section{Filomena Gerardo}

\section{Jean-Philippe Viriot-Durandall}

Dossier Editors

Copyright (C) 2015 (Gerardo, F, Viriot-Durandall, J-P.). Licensed under the Creative Commons Attribution Non-commercial No Derivatives. Available at http://cidades.dinamiacet.iscte-iul.pt/ 